\title{
RPD
}

\section{A BEHAVIOR ANALYSIS OF BRAZILIAN FARMERS BASED ON SUNK COST EFFECTS AND PROSPECT THEORY}

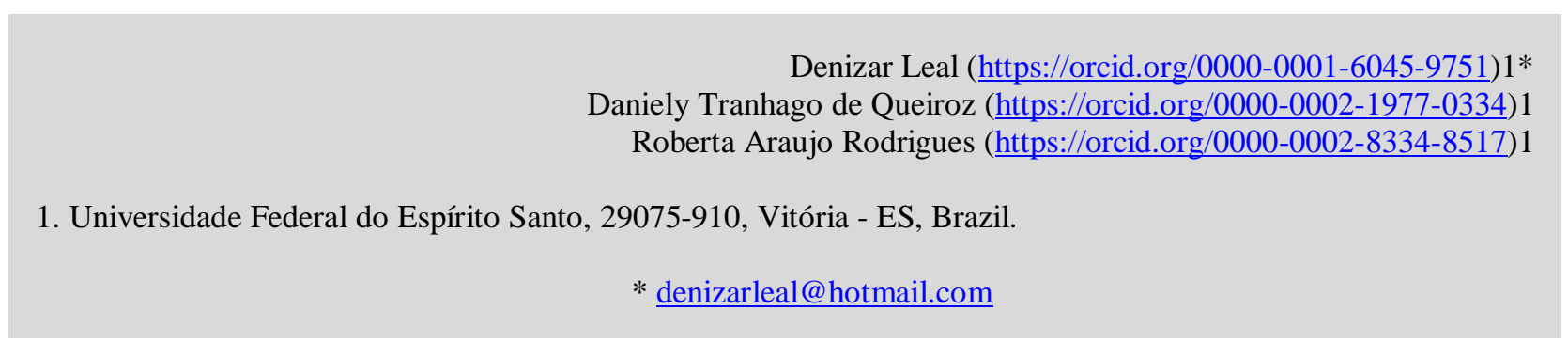

\section{Submitted: 06/10/2020. Accepted: 08/11/2020 Published: 12/11/2020}

\begin{abstract}
Purpose: identify whether the sunk cost effect is one of the reasons that make banana producers in Espírito Santo, a Brazilian state, make decisions that involve returning home with unsold production.

Methodology/Approach: It is an exploratory and descriptive study of multiple cases. The object of study was 17 banana producers from Espírito Santo, who sell their products in Supply Centers of Espírito Santo (CEASA). Data collection was carried out through interviews

Findings: The results found demonstrate that producers are reluctant to sell below cost price, noting that there is an influence of sunk costs in their decisions. Another finding is that the fear of loss, which is one of the pillars of the Prospect Theory, also influences the decisions of producers, in the sense of trying to avoid future losses

Research Limitation: the methodology used does not allow inferences about the behavior of all producers.

Originality/Value of paper: This study confirms that knowledge of costs in the decision-making process is fundamental in any business, since if producers were not influenced by the sunk cost effect, they would probably have better results in this activity.
\end{abstract}

KEYWORD: escalation of commitment, sunk cost, farmers, prospect theory, food waste.

\section{ANÁLISE COMPORTAMENTAL DE AGRICULTORES BRASILEIROS BASEADA NOS EFEITOS DO CUSTO AFUNDADO E A TEORIA DA PERSPECTIVA}

Propósito: identificar se o efeito dos custos perdidos é um dos motivos que levam os produtores de banana do Espírito Santo a tomar decisões que envolvem o retorno para casa com a produção não vendida.

Metodologia: É um estudo exploratório e descritivo de casos múltiplos. O objeto de estudo foram 17 produtores de banana do Espírito Santo, que comercializam seus produtos nas Centrais de Abastecimento do Espírito Santo (CEASA). A coleta de dados foi realizada por meio de entrevistas.

Resultados: Os resultados encontrados demonstram que os produtores relutam em vender abaixo do preço de custo, observando que há influência dos custos perdidos em suas decisões. Outra constatação é que o medo da perda, que é um dos pilares da Teoria da Perspectiva, também influencia as decisões dos produtores, no sentido de tentar evitar perdas futuras.

Limitação da pesquisa: a metodologia utilizada não permite inferências sobre o comportamento de todos os produtores.

Originalidade: Este estudo confirma que o conhecimento dos custos no processo de tomada de decisão é fundamental em qualquer negócio, pois se os produtores não fossem influenciados pelo efeito custos perdidos, provavelmente teriam melhores resultados nesta atividade.

PALAVRAS-CHAVE: escalada do comprometimento, custo afundado, agricultores, teoría da perspectiva, desperdicio de comida. 


\section{INTRODUCTION}

In the most diverse human activities, people should use a rational decision-making process (Schmidt, 2019), making choices through rational, consistent and decisive steps (Robbins, 2000), since by Modern Finance Theory, man was seen as economic and rational, having knowledge about all relevant aspects of the environment, able to calculate the consequences of the available choice alternatives, in order to maximize the result of a decision made (Fama, 1970; Scholtens and Oueghlissi, 2020). However, the decision-making process is complex and there are several factors that interfere in decision making, making rationality and logic not always the primary elements in the choice method.

In view of the observation of human behavior in the face of decision-making moments, questions arise in relation to normative/prescriptive theories, which seek to identify which would be the best decision to be made. This was the case of Kahneman and Tversky (1979) who developed the Theory of Prospect, which predicts that the information scenario can affect the decision-making process and that in many situations people act differently than predicted by economic theory. Thaler (1980) used Prospect Theory to conclude that decision makers resist accepting losses, often preferring to continue risking to recover the loss or expense they had. For Kahneman and Tversky (1979) people are averse to loss, which justifies risk-prone behavior when faced with the possibility of loss.

Because of loss aversion, a phenomenon called 'sunk cost effect' arises (Crompton, 2016). The sunk cost effect manifests itself as an individual's tendency to continue in a course of action in which resources have already been invested, be it money, effort or time, instead of opting for a new path that could bring him better returns (Arkes \& Blumer, 1985). This tendency can be caused by cognitive dissonance, which occurs with the conflict of attitudes, beliefs, and behavior (Chung e Cheng, 2018), and is not easy to be mitigated, either by experience (Leal, 2014) or by the frequency of feedback on the subject's performance (Chen et. al. 2020).

In Brazil, Borba and Murcia (2005), Murcia and Borba (2009), Rover et al. (2009), Silva et al. (2015), Grejo et al. (2016), Paraboni et al. (2019) Castro et al. (2019) are examples of studies that investigated the problem related to the sunk cost effect. Like most Brazilian studies, such research worked with hypothetical situations in investigating the various aspects related to the sunk cost effect. Few studies, including at the international level, such as those by Ross and Staw (1986, 1993), Staw, Barsade and Koput (1997) - which investigated the escalation of commitment process - have analyzed the influence of sunk costs in decisions in real situations. Staw (2005) argued that the main advances in understanding the escalation process, which includes the sunk cost effect, could be obtained through more case studies and quantitative field studies.

Costs and food waste are a phenomenon that deserves attention, in this sense, is the case of perishable food producers, who may be affected by the sunk cost effect when they return home with unsold products. International recent studies, Bonadonna et al. (2019), Ghosh et al. (2019) and Chaboud \& Moustier (2020), assesses different approaches applied to food waste management and its future. Different from these studies, this one deals with a Brazilian case, about producers who sell bananas at the Supply Centers of Espírito Santo (CEASA). Therefore, this study will seek to understand why the return with leftover products is quite significant on certain occasions when the market price is low. Considering the possibility that producers are failing to sell their product because they consider the cost of production in their decisions, this work proposes the following research question: Are banana producers influenced by the sunk cost effect when returning with the products without selling?

Thus, this study aims to identify whether the sunk cost effect is one of the reasons that make banana producers in ES make the decisions that involve returning home with unsold production. The research is justified, given the nature of this activity, many producers apparently make decisions conditioned to their experience or tradition, which suggests that they may be under the 
influence of the sunk cost effect. In addition, the question investigated becomes relevant since, from the prospect of the theory of sunk costs, a paradox may be probable, since the loss in return from unsold production may originate in the loss aversion and is causing a loss, even greater loss due to the fact that it is a perishable product.

The research is organized as follows: the next section presents a brief review of the literature, with constructs that address the influence of sunk costs in decisions. The third section deals with the material and the method used. Next, the research results are presented and discussed, followed by the conclusion and references used.

\section{LITERATURE REVIEW}

\subsection{Decision-making process}

The Modern Theory of Finance (Fama, 1970) is based on a rational decision-making structure that argues that man is a perfectly rational being. Bazerman and Moore (2014) indicate six steps to be followed to apply a totally rational decision-making process: (1) define the problem perfectly, (2) identify all criteria, (3) accurately weigh all criteria according to their preferences, (4) know all the relevant alternatives, (5) accurately evaluate each alternative based on each criterion and (6) calculate the alternatives accurately and choose the one with the highest perceived value. However, given the human limitation, it is difficult for the decision-maker to have the knowledge or capacity to satisfy all these steps, since the vastness of information available makes it impossible to analyze its entirety.

This lack of thorough analysis of all the information relevant to the rational choice process gives rise to the theory of limited rationality, proposed by Simon (1955). According to Simon (1957), full rationality is compromised by the limitation of the human capacity to formulate and solve complex problems, what he calls "limited rationality". In Robbins' (2005) perception, limited rationality is understood as the simplified construction of elements, considering essential aspects of a given situation, without obtaining all the complexity, valuing the relevant aspects perceived. Thus, the condition of limited rationality does not mean that human beings cease to be rational in carrying out their actions, but, due to their limitations, in decision-making it is impossible to perceive and analyze all available possibilities (Simon, 1965). Seeking to facilitate the complex decision-making process, the decision maker seeks simplifying resources, known as mental or heuristic shortcuts (Segantini et al., 2011). Thus, the individual makes use of these heuristic biases, using his experience, beliefs, culture, to streamline and simplify the choice process, leading him to irrational decisions.

In the decision-making process, the human being is not limited to reasoning only in an objective and logical way, so one cannot ignore that subjectivity and ambiguity are inherent to the process of human reasoning (Murcia \& Borba, 2009). Tversky and Kahneman (1974) also pointed out emotion as a human limitation that prevents self-control in the decision-making process. Despite the relevance of the Expected Utility Theory as a normative and prescriptive theory of decision making, it was observed that it was not possible to describe the decision-making process realistically without taking into account the emotions and feelings that people face in these cases (Kahneman, 2003). Thus, the Prospect Theory, proposed by Kahneman and Tversky (1979), seeks to explain the heuristic biases in decision making. 


\subsection{The Prospect Theory}

The Prospect Theory, developed by researchers Kahneman and Tversky (1979), explains cognitive biases in the decision-making process. The authors concluded that people make their choices in terms of gains and losses, in relation to a reference point adopted for the decision. If the individual's reference point is such that the results are better than those of the reference point, these are said to be gains, with a risk-averse position prevailing. If, on the contrary, the results are less than those of the reference point, they are said to be losses, with the risk propensity prevailing.

Shrader et al. (2020) uses prospect theory to examine relationships between effort invested in developing financial forecasts and risk taking. According to Kahneman et al. (1988), the Prospect Theory modifies the concept of utility since the results of the decision are deviations from a reference point that the decision maker adopts in the choice. According to the authors, people feel more the pain of loss than the pleasure achieved with an equivalent gain.

According to Kahneman and Tversky (1979), loss aversion is observed when agents tend to be risk averse when they are faced with two possibilities of gain with the same expected utility and tend to be risk-prone when the same possibilities present themselves in the market, concluding that the human being has no risk aversion, but loss aversion. Also according to the authors, the isolation effect demonstrates that to simplify the decision process, agents generally disregard a good part of the characteristics of each of the options of choice and centralize their analysis on the components that distinguish the options of choice.

Rover et al (2009) mention that for the Prospect Theory, a person does not analyze his financial situation based on his total wealth, as the perceived utility depends on the changes in that wealth. Monetary gains and losses are filtered by a value function. The value function developed by Kahneman and Tversky (1979), shown in Figure 1, illustrates the idea of Prospect Theory.

Figure 01: The Value Function

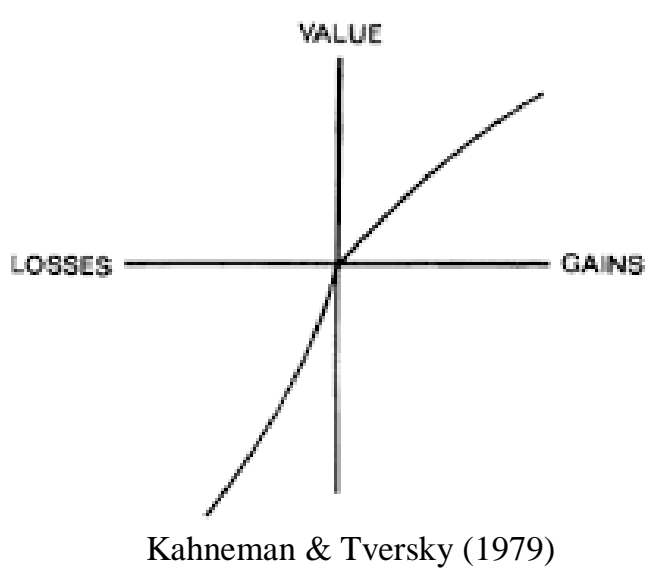

Kahneman and Smith (2002) explain that the hypothetical value function has an S shape, that is, it is concave for gains and convex for losses, with curvature at zero point.

The Prospect Theory contributes to the discussions about the sunk cost effect when explaining the individual's behavior, when he cannot articulate the risk and continues to persist in lost costs (Rover et al., 2009).

\subsection{Escalation of commitment}

The escalation of commitment is a bias that occurs in a sequence of decisions. It represents the commitment to a previously selected course of action (Sofis et al., 2015) to a point beyond what 
a rational decision-making model would prescribe (Bazerman \& Moore, 2013). Thus, people can make irrational decisions taking into account past rational decisions, for example, a person who detects an opportunity and invests in it, may feel more committed to continue in this course of action, investing more and more time and money, even if growth expectations are less favorable than before.

According to Leal (2014), there is a strong relationship between escalating commitment and sunk costs. The author mentions that research seems to consolidate the proposal that there is an irrational impact of sunk costs in decisions to 'escalate the commitment', in situations where the signs point to a need to review the course of action. Also, according to the author, the disclosure of the phenomenon of escalation of commitment justified the existence of a decision bias with a central characteristic: a tendency of people to continue investing in a course of action with probable negative consequences. In a five-year project, for example, after two years have passed and the results are not positive as planned, the individual does not want to admit the loss of time and resources, and thus remains committed to the project in an attempt to recover the resources used in the previous two years, that is, the past investment impacts the future decision, characterizing the sunk cost effect.

\subsection{Sunk Cost Effect}

Sunk costs are costs that have been incurred in the past and should not be considered for decision making. Just as 'past water does not move mills' says, sunk costs must be ignored, as they have already occurred, and it is not possible to change them with future decisions (Ross et al., 1995). The sunk cost effect occurs when, when deciding, the individual is influenced by taking into account the money, effort or time invested in a project, considering that it will no longer be recovered. (Arkes \& Blumer, 1985; Arkes \& Ayton, 1999).

Sunk costs can be seen in people's daily lives. They can be perceived in a student who feels obliged to finish an undergraduate course that has already started, even if he is not satisfied with his profession. As time, money and effort have already been invested in this course, the propensity to continue investing in this alternative is high. The effect of sunk costs when an individual buys a movie ticket is also perceived, and the probability that he will go to the movie is greater than if he had won this same ticket. However, only additional benefits and costs should be considered in the decision-making process. Thus, the fact that the ticket has been paid or not, should be irrelevant and it is up to the person to choose what he likes most (Rover et al., 2009).

There is some pressure from the individual himself when the invested project is in a risky situation (Arkes \& Blumer, 1985), with no acceptance of losses, a fact that influences his decision. This aversion occurs due to judgment for the bad choice. As a result, the individual is obliged to consider this sunk cost. Decision-makers do not like the feeling of having invested unnecessary time, money and effort (Murcia \& Borba, 2009). Thus, when a decision does not cause the expected results, the risk of investing even more is very high, which can bring even greater losses.

Friedman et al. (2007) argue that there are two distinct psychological mechanisms that may be related to the sunk cost effect: self-justification, as people do not want to assume that they made a wrong investment; and loss aversion, which causes individuals to apply more resources to try to "save" an investment already made.

In the view of Arkes and Blumer (1996), one of the reasons for the sunk cost effect to occur is the fact that people do not want to be considered "wasteful", which makes them seek to invest new resources in an attempt to recover sunk costs. Some studies carried out in Brazil aimed to investigate the sunk cost effect in the decision-making process. In the research carried out by Borba and Murcia (2005), the influence of the sunk cost effect on undergraduate students in accounting, administration and economics was noticed. 
Rover et al. (2009) pointed out that there are no significant differences in the choices of undergraduate students in the business area in relation to students in other areas, while Segantini et al. (2011) identified that the value of the investment can influence the choices of managers, that is, they can be influenced by the sunk cost effects.

In view of the aforementioned authors, it can be noted that both academics and managers end up being influenced by the sunk costs in the decision-making process, proving the existence of the sunk cost effect and, therefore, subsidizing the relevance of the study of this theme.

\section{MATERIAL AND METHODS}

This research adopts the multiple case study as an investigation strategy. According to Yin (2010), a case study is a form of empirical investigation that investigates a contemporary phenomenon in depth and its real-life context, especially when the limits between the phenomenon and the context are not clear. "The use of multiple cases provides evidence inserted in different contexts, contributing to the development of better-quality research" (Gil, 2002, p. 139).

According to the question and the established objectives, this study has an exploratory and descriptive nature. According to Gil (2009) in exploratory case studies, the researcher does not expect to obtain a definitive answer to the proposed problem, but rather a more accurate view of the problem in order to carry out a deeper research in the future. This author also mentions that this modality is recommended for little explored themes or when it is intended to approach them under new approaches. Gil (2002) highlights that the descriptive research aims to describe the characteristics of a given population or a certain phenomenon.

Given the inherent characteristics of a practical case, a group decision making (GDM) support model integrated with prospect theory-based consistency recovery strategies based on multiplicative probabilistic linguistic preference information is proposed (Nie and Wang, 2020). The preliminary stage of the research consisted of an interview with rural banana producers in Espírito Santo, who market their products at the Espírito Santo Supply Centers (CEASA), in April 2018. In this stage, we sought to learn more about the processes involved in this activity, as well as verifying the feasibility and relevance of the proposed investigation.

It is generally assumed that decision makers (DMs) are completely rational in common cross-efficiency evaluation models, which fail to consider the DM's risk attitude that plays an important role in the evaluation process (Liu, Song and Yang, 2019). Given the confirmation that the research was executable and pertinent, the object of study was 17 banana producers from Espírito Santo, who sell their products in CEASA. Data collection was carried out through interviews. These interviews were conducted based on a semi-structured script previously prepared based on the referenced literature, in order to identify whether the sunk cost effect is one of the reasons that make banana producers in Espírito Santo take the decisions that involve returning to house with unsold production.

\section{Why producers return home with unsold production}

A total of 17 interviews with banana producers were obtained and the anonymity of the interviewees was agreed. The approach was made in July 2018 and the interviews were recorded to avoid loss of information and, later, transcribed. The interviewees were chosen at random according to the identification of the banana production activity and the parts related to the question investigated were transcribed before the analysis.

Questions were asked with the intuition of knowing the profile of the interviewees, according to table 1 . According to the size of the property, 10 are characterized as small property and 7 as mini property, this classification according to Incra - National Institute of Colonization and 
Agrarian Reform, is defined by Law 8.629, of February 25 of 1993 and takes into account the fiscal module (and not just the length), which varies according to each municipality.

The vast majority entered the banana production business through the family. Regarding the average number of boxes they take to sell per week, eight producers take up to 200 boxes of bananas, six of them take up to 600 boxes and three take more than 600 boxes per week.

Table 1 - Profile of banana producers

\begin{tabular}{|c|c|c|c|c|c|c|}
\hline Interviewee & Property size & $\begin{array}{c}\text { Time in the } \\
\text { Market }\end{array}$ & $\begin{array}{l}\text { Produces } \\
\text { only } \\
\text { bananas }\end{array}$ & $\begin{array}{l}\text { How it got } \\
\text { into the } \\
\text { business }\end{array}$ & $\begin{array}{l}\text { Sells only own } \\
\text { production }\end{array}$ & $\begin{array}{c}\text { How many boxes } \\
\text { leads to CEASA } \\
\text { per week }\end{array}$ \\
\hline Producer 1 & 12,5 hectares & 22 years & $\begin{array}{l}\text { Did not } \\
\text { answer }\end{array}$ & $\begin{array}{l}\text { Through the } \\
\text { family }\end{array}$ & no & $\begin{array}{l}\text { Between } 100 \text { and } \\
200\end{array}$ \\
\hline Producer 2 & 7 hectares & 25 years & No & $\begin{array}{l}\text { Through the } \\
\text { family }\end{array}$ & no & $\begin{array}{l}\text { Between } 500 \text { and } \\
600\end{array}$ \\
\hline Producer 3 & 27 hectares & 44 years & No & $\begin{array}{l}\text { Through the } \\
\text { family }\end{array}$ & Yes & Between 20 and 30 \\
\hline Producer 4 & 40 hectares & 30 years & No & By choice & Yes & 600 \\
\hline Producer 5 & 13 hectares & 5 years & No & $\begin{array}{l}\text { Through the } \\
\text { family }\end{array}$ & no & $\begin{array}{c}\text { Between } 150 \text { and } \\
200\end{array}$ \\
\hline Producer 6 & 20 hectares & 30 years & $\begin{array}{l}\text { Did not } \\
\text { answer }\end{array}$ & By choice & Yes & $\begin{array}{c}\text { Between } 140 \text { and } \\
150\end{array}$ \\
\hline Producer 7 & 24 hectares & 10 years & Yes & $\begin{array}{l}\text { Shipping in } \\
\text { the region }\end{array}$ & no & 450 \\
\hline Producer 8 & 50 hectares & 10 years & Yes & $\begin{array}{l}\text { Through the } \\
\text { family }\end{array}$ & Yes & $\begin{array}{c}\text { Between } 450 \text { and } \\
600\end{array}$ \\
\hline Producer 9 & 50 hectares & 10 years & No & $\begin{array}{l}\text { Through the } \\
\text { family }\end{array}$ & no & 600 \\
\hline Producer 10 & 1 hectare & 37 years & No & $\begin{array}{l}\text { Through the } \\
\text { family }\end{array}$ & $\begin{array}{l}\text { Yes, but buy on } \\
\text { CEASA to resell }\end{array}$ & $\begin{array}{c}\text { Between } 500 \text { and } \\
750\end{array}$ \\
\hline Producer 11 & 25 hectares & 4 years & No & By choice & no & 900 \\
\hline Producer 12 & 11,3 hectares & 30 years & No & $\begin{array}{l}\text { Through the } \\
\text { family }\end{array}$ & no & 150 \\
\hline Producer 13 & 70 hectares & 45 years & No & $\begin{array}{l}\text { Through the } \\
\text { family }\end{array}$ & no & 800 \\
\hline Producer 14 & 25 hectares & 30 years & Yes & $\begin{array}{l}\text { Through the } \\
\text { family }\end{array}$ & no & 100 \\
\hline Producer 15 & 18 hectares & 10 years & No & $\begin{array}{l}\text { Through the } \\
\text { family }\end{array}$ & no & 120 \\
\hline Producer 16 & 16 hectares & 30 years & No & $\begin{array}{l}\text { Through the } \\
\text { family }\end{array}$ & Yes & Between 80 and 100 \\
\hline Producer 17 & 5 hectares & 20 years & No & $\begin{array}{c}\text { Through the } \\
\text { family }\end{array}$ & no & $\begin{array}{l}\text { Between } 200 \text { and } \\
250\end{array}$ \\
\hline
\end{tabular}

Figure 2, below, in which the main producing regions can be seen, shows the agricultural distribution in the state. CEASA is in the metropolitan region. 


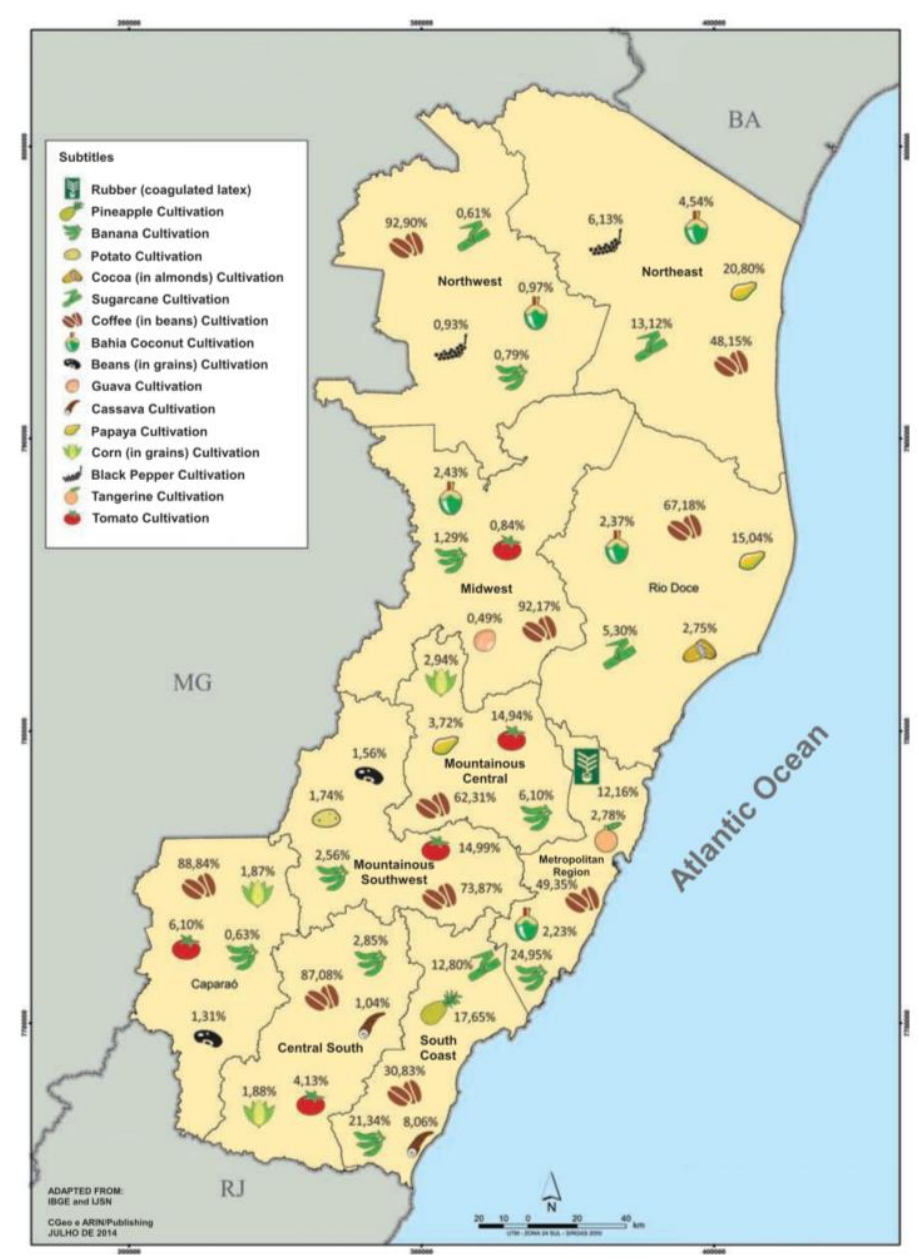

Figure 2 - distribution of agricultural production in Espírito Santo

Seven questions were asked to investigate whether the sunk cost is one of the reasons why producers return home with unsold production. For the purposes of the discussion, some questions were unified, as will be shown in this study.

\section{Can you identify how much it costs to produce a banana box? What makes up this cost?}

This question was presented with the intention of subsequently identifying the extent to which producers would accept to make the selling price more flexible in situations where there is a great possibility of loss due to the fact that they are unable to sell the products. According to economic theory, past sunk costs should not influence future decision making. In the case of producers, who are already in CEASA with bananas and there is no demand for the product, neither fixed costs nor variable costs should influence the decision-making process for the formation of the minimum sale price, as these are past costs. In the situation of low demand for the product, the market price often falls to levels lower than what they estimate to be the cost of the product and many producers return home with what was not sold.

The analysis of the data obtained reveals that only two producers answered that they were unable to identify the production cost of a banana box. However, the information of the others is not accurate and varies between $\mathrm{R} \$ 10.00$ and $\mathrm{R} \$ 20.00$, with the values of $\mathrm{R} \$ 10.00$ (five producers) and $\mathrm{R} \$ 15.00$ (six producers) predominating. One factor that may have contributed to this variation is the difference in the type of banana grown, as this was not a point addressed in the interview. Since most producers reported knowing the cost price, the composition of that price was asked. 
Again, the information provided by them varied widely: for example, only one producer indicated that seedlings are part of the cost; the items most cited by producers were labor, fertilizer, packaging, and freight. The producers cited several variable costs and variable expenses, however, most of them cited labor, which is characterized as a fixed cost and difficult to be measured in the activity performed by them.

However, as will be shown below, due to the sunk cost effect, the cost price is a factor that affects the decision-making process of the minimum selling price of several producers. Thus, there is also the aggravation that producers form this cost price considering fixed costs attributed in an intuitive way. According to Ribeiro (2009), the variable or direct costing system considers as production cost only direct or variable costs, with variable costing being the parameter in costs for the decision-making process.

In the case of these producers, it is noticeable that they are not aware of the concept of contribution margin, which could help them to be more flexible in negotiating the sale price, even influenced by the effect of sunk costs. A problem in the managerial use of appropriate fixed costs, according to Martins (2003), is the very nature of fixed costs that exist independently of production.

\section{Under what conditions are you willing to sell below cost? How do you see loss in this case?}

Only Producer 16 cited the attempt to reduce the loss as a condition of selling below cost: "we did not want to sell below that, but we often have to sell everything below to avoid losing everything". Eleven producers said that only when market forces impose it and three under no circumstances are willing to sell below cost. The two producers who are unable to identify the cost price just follow the market price, not knowing when to sell below the cost price. Apparently, most of the producers that indicate to follow the market price would not be influenced by the sunk costs. However, as will be noted in the following questions, some are in contradiction and almost all establish a minimum price close to what they consider cost.

In theory, sunk costs should not be considered when deciding. Jiambalvo (2009) warns that because they are costs that occurred in the past, they are not relevant for decision making since they do not change when decisions are made. However, we observed the opposite behavior on the part of some interviewed producers. Producer 1 said: "Unfortunately, at the time when there is a lot, we are forced to sell below the cost price, that's the market, then we work at a loss", while Producer 4 said: "I'm the type of that guy that I don't usually go too far, not in any case I sell below the cost price, or when the market is less, very difficult", and continues: "I give to the poor, but below the cost price I don't sell , I distribute to everyone". This producer prefers to donate rather than sell below the cost price, that is, the producer is so attached to a past cost, that of production, that he ends up earning nothing. There is also an attempt to justify the decision not to sell below the cost price by saying that it will make donations, confirming what the literature says that, when there is a decision bias of the sunk cost effect, people seek justifications for the decision taken.

\section{About the question of how they view losses in this case.}

Producer 5: "it's the ups and downs, one day we win, the other day we lose, you know; there are times when we win, when it is higher we profit a little more ", another 12 producers see as losses that will be compensated in moments of profit, which is natural in this type of activity. The two producers who do not know the cost price cannot identify the loss in this case. Producer 6 replied: "lamenting, right; I told my wife that I have to stop this. I'm just taking a loss; I did not stop thinking that the business would improve, but now I think I will have to stop altogether, go to another branch", that is, this producer regrets the loss so much that he thinks about stopping banana production. 


\section{In cases of leftovers, what is the minimum price you are willing to sell the banana box?}

Regarding this question, one producer did not answer, one producer has no spare cases, seven answered that the minimum price is the cost price, seven indicated a minimum price below the cost price and one answered an arbitrary value, once who doesn't know the cost price.

Producer 7 is the case where there is no surplus, he says: "when there was a little left, I increased it one more day, right; I came two, now I come three days so that it doesn't happen (the surplus); if one day is left, I will bring it the next ". The producer demonstrates knowledge through his experience in the market and when he perceives potential leftovers, he increases his periodicity of trips to CEASA, also reporting that the quantity taken is reduced.

In the seven producers who responded that the minimum price is cost price, we can see the sunk cost effect as consequence of loss aversion. According to Araújo and Silva (2007), the concept of "loss aversion" says that people are not averse to risk but to loss, since the pain of a loss is greater than the pleasure of an equivalent gain, that is, it is better not to lose $\mathrm{R} \$ 100.00$ than to earn $\mathrm{R} \$ 100.00$. This behavior can be observed in the decision-making process of these producers, since the fear of losing resources, time and efforts invested in production, makes them refuse to sell below the cost price in cases of surplus. See Producer 1's speech: "when the minimum is left over is $\mathrm{R} \$ 15.00$ (cost price); for less than that I take it back and donate, but I don't sell for less".

Among these seven producers there was a case of contradiction. Producer 16, as already mentioned, indicated as a condition for selling below the cost price the attempt to get rid of a total loss, but that same producer says that the cost price is his price limit in case of surplus. What's more, Producer 16 shows an aversion even to future losses when he says: "it has to be the cost price, because it is difficult for us to sell less; and it also causes a bad habit in the staff, sometimes we sell today below (the cost price) and next week the staff wants to buy again at the same price". In the same vein, Producer 11 says: "If you do it one day (sell below cost), people generally want you to do it every day". In this case, the cognitive dissonance resulting from perceiving the sale below cost (Chung \& Cheng, 2018), causes the paradox between selling and returning home with the production.

These producers fear the loss of returning customers, asking for a price below cost again. Producer 12, on the other hand, is concerned about the loss due to the low price of the product on the market: "I would not sell (below the cost price) because if I sell it, tomorrow it will be lower and more and more banana will be left on the market". Thus, these producers give up to reduce at least part of their loss with the sale below the cost price for fear of losing in future sales.

Among the producers who indicated a minimum price below the cost price, we have Producer 10, who says that he sells at any price offered and justifies: "there is no solution, you have no other solution, you have to do this, or take it away and throw it away". This is a case in which we observe the non-impact of the sunk cost effect on its decision-making process.

Another five producers, despite not considering the cost price in their decisions, establish a minimum sale price, as exemplified by the statement by Producer 15: "selling below $\mathrm{R} \$ 5,00$ (minimum price stipulated) is no use, it will not solve my problem; I throw it away, it's too much abuse, it's crazy". These producers still suffer from the sunk cost effect, as they stipulate a minimum price required for their work and thus declare it an abuse to sell below that price, that is, they are considering a past effort in decision making.

There is a certain contradiction in the speech of all six producers, since they all responded that only when market forces impose would they be willing to sell below cost. However, it can be concluded that this contradiction may have occurred due to pure lack of attention to the situation of leftovers when the first response was made.

Finally, there is also the case of Producer 6 who initially says that under no condition does he sell below the cost price, which would indicate the incidence of the sunk cost effect, but when 
answering the above question he says: "today it would be less than R 2,00 that I wouldn't sell, which is the price of the box (packaging)", characterizing contradiction. From this report, we identified that this producer is not under the sunk cost effect, since it stipulates the cost of the sale as the minimum sale price, since when selling it is necessary to deliver the packaging box, which in case of return can be reused.

\section{If you return home with unsold production, what do you do with those leftovers? In cases of feeding animals with unsold production, can you save on the purchase of feed?}

The purpose of these questions was to verify if the alternatives of destination of the unsold production result in a better result than the sale at any price offered, and thus, there is a rational reason for the return with surplus.

Respondents cited three alternatives: donation, throwing away and feeding animals. In relation to animal feed, there could be savings on feed that would justify the return on unsold production, so the second question was asked. Ten producers said that they feed animals with leftovers, however, there was no consensus regarding the economy with feed.

Some producers said there was an economy, as Producer 9 says: "it saves, certainly, because they (the animals) eating bananas stop eating grass or feed", while other producers said that there is no economy. It should be noted that this divergence is due to the fact that there really is savings, but it is not substantial, as Producer 2 said: "it saves a little, but it doesn't make much difference" and Producer 16: "it doesn't make much difference (the economy)".

Therefore, producers who answered that there is no economy, probably save, but consider this to be insignificant. Thus, it can be said that the economy with feed is insignificant, noting that the feeding of animals is not a relevant reason to return home with unsold production.

\section{Presentation of hypothetical situation.}

In addition to the questions asked, some producers were presented with the following hypothetical situation: in cases of leftovers, selling the production for $\mathrm{R} \$ 100.00$ at a cost of $\mathrm{R} \$$ 150.00 , explaining that in this case, the loss of $\mathrm{R} \$ 150.00$ caused by the return with unsold production would decrease to $\mathrm{R} \$ 50.00$.

To this situation, Producer 1 replied: "you are already at a loss, so R $\$ 100.00$ less or more, you know, it won't make much difference". This producer disregards other characteristics of the sale below the cost price and focuses only on the loss caused by this choice. However, selling below cost minimizes the loss, a fact that is not considered with due importance by the producer, who is under the influence of the sunk cost effect when he is strongly attached to the cost price.

Producer 14, who initially was not willing to sell at any price in case of leftovers, after exposing the hypothetical situation says: "it is certainly reduced (the loss), we sell (at any price) not to take come back and save a little bit, right?". Before that producer established a minimum price of $\mathrm{R} \$ 5.00$, but after exposing the hypothetical situation and understanding that any value offered causes a decrease in the total loss, the sale was accepted at any price, mitigating the sunk cost effect.

Once the respondents have become aware of the certain loss when they do not sell the production, their decision becomes more rational. Once again, the fear of certain loss acts positively in the decision-making process, since part of the invested resources is recovered. 


\section{CONCLUSION}

This research aimed, through a multiple case study carried out with producers who commercialize banana production in CEASA, to identify whether the sunk cost effect is one of the reasons that make these producers make the decision to return home with unsold production.

The results found in an exploratory way in this work demonstrate a strong interference of the cost price in the decisions of the respondents. As found in the interviews conducted, many refuses or are reluctant to sell below the cost price, evidencing the influence of the sunk cost effect on decisions to return home with production without selling. The effect is characterized, in this case, by the fact that the production cost is an irrecoverable cost and should not be considered in these cases. As the unsold product, as it is perishable, will only be used to feed animals (in some cases) or will be lost, selling it for less than the cost would be a way of reducing losses related to the investment made in production, transport and commercialization.

It was also found that, in addition to the cost price, the time and effort invested in production interfere in the interviewees' decision-making process, once again characterizing the sunk cost effect (Arkes \& Blumer, 1985). As can be seen in the justifications presented by the producers, the sunk cost effect arises as a result of the loss aversion, being even identified aversion to future losses, confirming the paradox raised in the introduction of this research that the fear of loss may be leading producers to make decisions that imply greater losses.

This study contributes to studies on the influence of sunk costs in the context of decisions, confirming that this is a problem that must be observed in the most diverse areas in society. In this sense, it is attested that knowledge of costs in the decision-making process is fundamental in any business, since if producers were not influenced by the sunk cost effect, they would probably have better results in this activity.

The main contribution of this study was to demonstrate that the sunk cost effect and, consequently, the fear of loss, are phenomena that significantly affect people's choices, even when they already have experience in the activity (Leal, 2014). Thus, it is suggested that further research be carried out in this regard in other sectors, as well as the expansion of this research with the possibility of making inferences regarding the results obtained, that is, quantitative research, but with a non-experimental nature.

As the experience is not able to avoid the effect of sunk costs in decisions, it is necessary that university extension activities be carried out with society (in this case, banana producers), in order to help them understand the sunk cost traps. and avoid greater losses in their work activity.

\section{REFERENCES}

Arkes, H. R., \& Ayton, P. (1999). The sunk cost and concorde effects: are humans less rational than lower animals? Psychological Bulletin, 125(5), 591-600. https://doi.org/10.1037/0033-2909.125.5.591

Arkes, H. R., \& Blumer, C. (1985). The psychology of sunk costs. Organizational Behavior and Human Decision Process, 35,124-140. https://doi.org/10.1016/0749-5978(85)90049-4

Bazerman, M. H., \& Moore, D. A. (2013). Judgment in managerial decision making. 8. ed. New Jersey: Wiley.

Bazerman, M. H., \& Moore, D. A. (2014). Processo decisório. 8 ed. Tradução de Daniel Vieira. Rio de Janeiro: Elsevier.

Bonadonna, A., Matozzo, A., Giachino, C., \& Peira, G. (2019). Farmer behavior and perception regarding food waste and unsold food. British Food Journal. 121(1), 89-103. https://doi.org/10.1108/bfj-12-2017-0727

Borba, J. A., \& Murcia, F. (2005). A influência dos custos perdidos (sunk costs) no processo de tomada de decisão: um estudo empírico baseado em cenários de decisão. In. IX Congresso Internacional de Custos. Florianópolis-SC, Brazil.

Castro, K. P. D., Silva, L. H. S., \& Marinho, A. (2019). Análise Da Fusão Azul-Trip Sob A Ótica Dos Ganhos De Eficiência. Revista de Economia Contemporânea, 23(1). https://doi.org/10.1590/198055272315 
Chaboud, G., \& Moustier, P. (2020). The role of diverse distribution channels in reducing food loss and waste: The case of the Cali tomato supply chain in Colombia. Food Policy, 101881. https://doi.org/10.1016/j.foodpol.2020.101881

Chen, DF, Chen, PK, Chung, SH, Cheng, KC, \& Wu, CH. (2020). The influence of performance feedback frequency and affective commitment on the sunk cost effect. Manage Decis Econ. 41,873-88.2 https://doi.org/10.1002/mde.3144

Chung, SH., \& Cheng, KC. (2018). How does cognitive dissonance influence the sunk cost effect? Psychology Research and Behavior Management. 11, 37-45. https://doi.org/10.2147/prbm.s150494

Crompton, L. C. (2016). Implications of prospect theory for the pricing of leisure services. Leisure Sciences. 38(4), 315-337. https://doi.org/10.1080/01490400.2015.1107516

Fama, E. F. (1970). Efficient capital markets: a review of theory and empirical work. The Journal of Finance, 25(2), 383-417. https://doi.org/10.2307/2325486

Friedman, D., Pommerenke, K., Lukose, R., Milam, G., \& Huberman, B. (2007). Searching for the sunk cost fallacy. Experimental Economics. 10(1), 79-104. https://doi.org/10.1007/s10683-006-9134-0

Ghosh, R., \& Eriksson, M. (2019). Food waste due to retail power in supply chains: Evidence from Sweden. Global food security, 20, 1-8. https://doi.org/10.1016/j.gfs.2018.10.002

Gil, A. C. (2002). Como elaborar projetos de pesquisa. 4. ed. São Paulo: Atlas.

Gil, A. C. (2009). Estudo de caso. São Paulo: Atlas.

Grejo, L. M., Faia, V. S., \& Abbas, K. (2016). Avaliação do efeito sunk cost na tomada de decisão de acadêmicos de ciências contábeis e administração. Revista de Administração, Contabilidade e Economia da Fundace, 6(2). https://doi.org/10.13059/racef.v6i2.331

Instituto Jones dos Santos Neves. (2014). Boletim técnico - agricultura capixaba 2012-2014. Available in: http://www.ijsn.es.gov.br/component/attachments/download/4814

Jiambalvo, J. (2009). Contabilidade gerencial. Rio de Janeiro: LTC.

Kahneman, D. (2003). Maps of bounded rationality: Psychology for behavioral economics. The American Economic Review, 93(5), 1449-1475. https://doi.org/10.1257/000282803322655392

Kahneman, D., \& Tversky, A. (1979) The prospect theory: an analysis of decision under risk. Econometrica. 47(2), 263-392. https://doi.org/10.2307/1914185

Kahneman, D., Slovic, P., \& Tversky, A. (1988). Judgment under uncertainty: heuristics and biases. Cambridge: Cambridge University Press.

Leal, D. (2014). O papel de custos afundados em decisões de alocação de recursos. Tese (Doutorado em Administração) - Instituto COPPEAD de Administração, Universidade Federal do Rio de Janeiro. Rio de Janeiro, Brazil.

Liu, H. H., Song, Y. Y., \& Yang, G. L. (2019). Cross-efficiency evaluation in data envelopment analysis based on prospect theory. European Journal of Operational Research, 273(1), 364-375. https://doi.org/10.1016/j.ejor.2018.07.046

Macedo Júnior, J. S. Teoria do prospecto: uma investigação utilizando simulação de investimentos. (2003). Tese (Doutorado em Engenharia de Produção) - Universidade Federal de Santa Catarina - UFSC, Florianópolis, Brazil.

Martins, Eliseu. (2003). Contabilidade de custos. 9. ed. São Paulo: Atlas.

Mineto, C. A. L. (2005). Percepção ao risco e efeito disposição: uma análise experimental da teoria dos prospectos. Tese (Doutorado em Engenharia de Produção) - Universidade Federal de Santa Catarina - UFSC, Florianópolis, Brazil.

Moon, H. (2001). Looking forward and looking back: integrating completion and sunk-cost effects within an escalation-of-commitment progress decision. Journal of Applied Psychology, 86(1) 104-113. https://doi.org/10.1037/0021-9010.86.1.104

Murcia, F. D., Borba, J. A. (2009). Um Estudo Empírico sobre os Efeitos dos Sunk Costs no Processo Decisório dos Indivíduos: Evidências dos Estudantes de Graduação de uma Universidade Federal. Revista Contabilidade, Gestão e Governança, 9(2). https://doi.org/10.11606/t.48.2013.tde-13022014-120236

Nie, R. X., \& Wang, J. Q. (2020). Prospect theory-based consistency recovery strategies with multiplicative probabilistic linguistic preference relations in managing group decision making. Arabian Journal for Science and Engineering, 45(3), 2113-2130. https://doi.org/10.1007/s13369-019-04053-9 
Paraboni, A. L., Campara, J. P., Costa Jr, N. C. A. D., \& Lima, M. V. A. D. (2019). Custos afundados: a decisão em grupo faz diferença? Revista Brasileira de Gestão de Negócios, 21(1), 136-151.

Ribeiro, O. M. (2009). Contabilidade de custos. São Paulo: Saraiva.

Robbins, S. P. (2000). Administração. Mudanças e perspectivas. São Paulo: Saraiva.

Robbins, S. P. (2005). Comportamento organizacional. São Paulo: Prentice Hall.

Ross, J., \& Staw, B. M. (1986). Expo 86: an escalation prototype. Administrative Science Quarterly, 32, $274-297$. https://doi.org/10.2307/2392791

Ross, J., \& Staw, B. M. (1993). Organizational escalation and exit: the case of Shoreham nuclear power plant. Academy of Management Journal, 36, 701-738. https://doi.org/10.2307/256756

Rover, S., Werges. A. F. E., Tomazzia, E. C., \& Borba, J. A. (2011). Efeito sunk costs: avaliação da influência do custo perdido no processo de tomada de decisão dos gestores das empresas de construção civil. In: Congresso Anpcont, 5. Vitória, Brazil.

Schmidt, A. T. (2019). Getting real on rationality—Behavioral science, nudging, and public policy. Ethics, 129(4), 511543. https://doi.org/10.1086/702970

Scholtens, B., \& Oueghlissi, R. (2020). Shocks and fish stocks: The effect of disasters and policy announcements on listed fishing companies' market value. Business Strategy and the Environment. https://doi.org/10.1002/bse.2601

Shrader, R. C., Simon, M., \& Stanton, S. (2020). Financial forecasting and risky decisions: an experimental study grounded in Prospect theory. International Entrepreneurship and Management Journal, 1-15. https://doi.org/10.1007/s11365-020-00697-4

Silva, A. A. N., Araújo, A. H. P., Franco, I. F., Silva, D. A., \& Silva, M. A. (2015). Efeito Sunk Costs no processo de tomada de decisão: uma análise sob a percepção de discentes. XXII Congresso Brasileiro de Custos, Foz do Iguaçú, Brazil.

Simon, H. A. (1955). A behavioral model of rational choice. Quarterly journal of economics, 69(1), 99-118.

Simon, H. A. (1957). Administrative Behavior: a study of decision-making processes in administrative organizations. 2 ed. New York: McMillan.

Simon, H. A. (1965). Comportamento administrativo: estudos dos processos decisórios nas organizações administrativas. Rio de Janeiro: Fundação Getúlio Vargas.

Sofis, M. J., Jarmolowicz, D. P., Hudnall, J. L., \& Reed. D. D. (2015). On sunk costs and escalation. The Psychological Record, 65, 487-494. https://doi.org/10.1007/s40732-015-0124-5

Staw, B. M. (2005). The escalation of commitment: steps toward an organizational theory. In: SMITH, K. G.; HIT, M. A. (Ed.). Great Minds in Management: the process of theory development. New York: Oxford University Press.

Staw, B. M. Barsade, S. G., \& Koput, K. W. (1997). Escalation at the credit window: a longitudinal study of bank executives' recognition and write-off of problem loans. Journal of Applied Psychology, 82(1), 130-142. https://doi.org/10.1037/0021-9010.82.1.130

Thaler, R. (1980). Toward a positive theory of consumer choice. Journal of Economic Behavior and Organization, 1,39-60. https://doi.org/10.1016/0167-2681(80)90051-7

Tversky, A., \& Kahneman, D. (1974). Judgment under uncertainty: heuristics and biases. Science, 185(4157), 11241131. https://doi.org/10.1126/science.185.4157.1124

Yin, R. K. (2010). Estudo de Caso - Planejamento e Métodos. 4ª edição, Porto Alegre: Bookman. 
DECLARATION OF CONTRIBUTIONS TO THE ARTICLE - CRediT

\begin{tabular}{|c|c|c|c|}
\hline ROLE & DLeal & DQueiroz & RRodrigues \\
\hline $\begin{array}{l}\text { Conceptualization - Ideas; formulation or evolution of overarching research goals and } \\
\text { aims. }\end{array}$ & $\mathrm{X}$ & $\mathrm{X}$ & $\mathrm{X}$ \\
\hline \multicolumn{4}{|l|}{$\begin{array}{l}\text { Data curation-Management activities to annotate (produce metadata), scrub data and } \\
\text { maintain research data (including software code, where it is necessary for interpreting } \\
\text { the data itself) for initial use and later re-use. }\end{array}$} \\
\hline $\begin{array}{l}\text { Formal analysis - Application of statistical, mathematical, computational, or other } \\
\text { formal techniques to analyze or synthesize study data. }\end{array}$ & $\mathrm{X}$ & $\mathrm{X}$ & $\mathrm{X}$ \\
\hline \multicolumn{4}{|l|}{$\begin{array}{l}\text { Funding acquisition - Acquisition of the financial support for the project leading to } \\
\text { this publication. }\end{array}$} \\
\hline $\begin{array}{l}\text { Investigation }- \text { Conducting a research and investigation process, specifically } \\
\text { performing the experiments, or data/evidence collection. }\end{array}$ & $\mathrm{X}$ & $\mathrm{X}$ & $\mathrm{X}$ \\
\hline Methodology - Development or design of methodology; creation of models. & $\mathrm{X}$ & $\mathrm{X}$ & $\mathrm{X}$ \\
\hline $\begin{array}{l}\text { Project administration - Management and coordination responsibility for the research } \\
\text { activity planning and execution. }\end{array}$ & $\mathrm{X}$ & & \\
\hline \multicolumn{4}{|l|}{$\begin{array}{l}\text { Resources - Provision of study materials, reagents, materials, patients, laboratory } \\
\text { samples, animals, instrumentation, computing resources, or other analysis tools. }\end{array}$} \\
\hline \multicolumn{4}{|l|}{$\begin{array}{l}\text { Software - Programming, software development; designing computer programs; } \\
\text { implementation of the computer code and supporting algorithms; testing of existing } \\
\text { code components. }\end{array}$} \\
\hline \multicolumn{4}{|l|}{$\begin{array}{l}\text { Supervision - Oversight and leadership responsibility for the research activity } \\
\text { planning and execution, including mentorship external to the core team. }\end{array}$} \\
\hline $\begin{array}{l}\text { Validation - Verification, whether as a part of the activity or separate, of the overall } \\
\text { replication/reproducibility of results/experiments and other research outputs. }\end{array}$ & $\mathrm{X}$ & $\mathrm{X}$ & $\mathrm{X}$ \\
\hline $\begin{array}{l}\text { Visualization - Preparation, creation and/or presentation of the published work, } \\
\text { specifically visualization/data presentation. }\end{array}$ & $\mathrm{X}$ & $\mathrm{X}$ & $\mathrm{X}$ \\
\hline $\begin{array}{l}\text { Writing - original draft - Preparation, creation and/or presentation of the published } \\
\text { work, specifically writing the initial draft (including substantive translation). }\end{array}$ & $\mathrm{X}$ & $\mathrm{X}$ & $\mathrm{X}$ \\
\hline $\begin{array}{l}\text { Writing - review \& editing - Preparation, creation and/or presentation of the } \\
\text { published work by those from the original research group, specifically critical review, } \\
\text { commentary or revision - including pre- or post-publication stages. }\end{array}$ & $\mathrm{X}$ & & \\
\hline
\end{tabular}

